University of Nebraska - Lincoln

DigitalCommons@University of Nebraska - Lincoln

Library Philosophy and Practice (e-journal)

Libraries at University of Nebraska-Lincoln

Winter 8-31-2020

\title{
Analysis of the Altmetric top 100 Altmetric Attention Score Coronavirus publications
}

Lambodara Parabhoi

India Institute of advanced Study, Rashtrapati Nivas, Shimla, suresh19871987@gmail.com

Follow this and additional works at: https://digitalcommons.unl.edu/libphilprac

Part of the Library and Information Science Commons

Parabhoi, Lambodara, "Analysis of the Altmetric top 100 Altmetric Attention Score Coronavirus publications" (2020). Library Philosophy and Practice (e-journal). 4426.

https://digitalcommons.unl.edu/libphilprac/4426 


\title{
Analysis of the Altmetric top 100 Altmetric Attention Score Coronavirus publications
}

\author{
Lambodara Parabhoi \\ Indian Institute of Advanced Study, Library, IIAS Shimla \\ Shimla, HP, 171005, IN \\ suresh19871987@gmail.com;laparabhoi@iias.ac.in
}

\begin{abstract}
:
The emergence of the Covid-19 pandemic has led to the publication of many scientific papers. The goal of the present research was to analyze these papers using the Altmetric Attention Score (AAS). Statistics for 100 publications with high AAS scores were selected and exported from the Dimension database on May $22^{\text {nd }} 2020$. The major findings were that these publications were published in 34 different journals or preprint repositories. More than one-third of the total of 657,350 social media posts were collected from the Twitter platform. The top contributing countries were China, followed by the USA. The paper "The proximal origin of SARS-CoV-2" by Andersen, Kristian G., etal., 2020 had the highest AAS (33 514). These findings may help others to design studies of the AAS in Coronavirus literature and compare them with traditional citations.
\end{abstract}

Keywords: Altmetrics, Altmetrics Attentions Score, Coronavirus publications, Covid-19

\section{Introduction}

Covid-19 or Coronavirus has affected almost all countries in the world after originating in Wuhan, Hubei Province, China, in early December 2019 (Valencia, 2020; Tan \&Aboulhosn, 2020). From there it spread very rapidly ( $\mathrm{Li}$ et al., 2020) and was declared a pandemic by the World Health Organization (WHO) in March 2020 (Valencia, 2020; Thelwall\& Levitt, 2020). According, to the WHO website, there were 8,223,454 confirmed cases, including 444,813 deaths, by 18 June 2020, with the USA having the highest number(2,126,027), followed by Brazil $(9,23,189)$, Russian Federation $(553,301)$ and India 366,946 respectively(Wordl Health Organization, 2020). The pandemic has led many countries to try to develop a vaccine against COVID-19. Although, many countries have officially reported that a vaccine in clinical trials, there have not yet been any patented. Similarly, many studies have been published, with 21,395 publications being listed in the Dimensions database, with high Altmetric Attention Scores (AAS) (Kousha et al., 2020).

The problem is to speed-up determination of the relative importance and usefulness of all this literature. Traditionally, it was believed that highly-cited papers would always be recognized but there is a considerable time between publication and citation (Akers, 2017; Thelwall\& Nevill, 2018). AAS give the real-time impact of papers by including mentions on the internet and in social media (Bornmann \& Haunschild, 2018; Dinsmore, Allen, \& Dolby, 2014). Various databases, such as PLOS, PlumX, and Dimension, are prominent in providing AAS data to indexed literature. Apart from some papers published in a Scientometrics study on Coronavirus (Kousha et al., 2020; Shri Ram, 2020) however, there is no study published on papers with high AAS on Coronavirus literature. Hence, this study has conducted using the Dimension database to remedy this.

\section{Review of Literature}

In recent years, there has been a growing literature on the impact of highly cited papers indifferent areas (Moon et al., 2020; Kim, Kim, Park, Yoon, \& Bae, 2019). For instance, a recent study analyzed the top 100 AAS publications on radiology, nuclear medicine, and medical imaging (Moon et al., 2020). Similarly, (Kim et al., 2019) reviewed the 100 top publications related to nervous system inflammatory demyelinating disease and found that there was no significant 
correlation between AAS and journal impact factor. In a very recent study concerning Covid-19 (Kousha et al., 2020) compared various indexed databases and found that coverage was greater in Google Scholar and Dimension than in Scopus, PubMed, and Web of Science. (Shri Ram, 2020) reported that 18,003 publications on Coronavirus were documented between 1970 and 2019. Of these, the United States accounted for $31.36 \%$ and China $13.67 \%$, while $6.51 \%$ were published in the Journal of Virology and The University of Hong Kong was a top contributor. (Thelwall, 2018) compared Scopus citations with AAS for papers published during 2013 in 35 research fields in arts and humanities and social sciences and found that the AAS was zero in all fields. When (Verma \& Madhusudhan, 2019) compared highly-cited Indian and Chinese papers published between 1989 and 2017, and listed on Digital Library, they found that the Indian publications had higher AAS than did the Chinese papers.(Babu \& Vysakh, 2019) compared the 10 most highly cited papers published in Nature with their AAS and found a high correlation between high citations and AAS. Further authors (Babu \& Vysakh, 2019) noted that Mendeley was generally accepted as the medium through which to share scientific information and was highly correlated with tweets in the UK and USA. (Rangaswamy \& H, 2019) reported that, for the top five journals in library and information science, comparison of Google scholar metrics with AAS showed that the majority of the AAS came from Mendeley. (Zhang et al., 2019)reported that highly-cited papers related to ecosystem services showed that 132 of the highly-cited papers published between 2005 and 2014 were published in three major journals, Ecological Economics, PNAS, and Ecological Indicators. (Araújo et al., 2017) conducted a study of high AAS publications related to Parkinson's disease. When high AAS and traditional citation metrics for 20 papers were compared, it was found that most of these publications were published in premier journals, although one was published in a second-rank journal.In an analysis of 7518 publications in 104 Iranian journals, (Kolahi et al., 2019)found that a combination of inclusion in an Altmetrics database and publication in the International Journal of Preventive Medicine resulted in higher AAS than those for other Iranian journals. A notable study by(Banshal et al., 2019) of a large multi-disciplinary dataset extracted from Web of Science and its associated. Altmetrics covered a large amount of literature related to medical sciences and biology than other disciplines. Further reported that Mendeley and Twitter were considered to be more reliable source when scientific articles were shared. (Scotti et al., 2020) examined 3176 publications and correlated with traditional citation metrics. Study reported that 0.3 statistically significant correlations found however, low correlation between traditional citations and Altmetrics.

\section{Objectives:}

RQ1: Which social media platforms were used to share academic publications related to Coronavirus publications?

RQ2. To what extent have highly AAS papers been published in reputed journals related to Coronavirus publications?

RQ3. Which country contributed the highest number of Coronavirus publications with high AAS?

RQ4. Which institute contributed the highest number of Coronavirus publications with high AAS?

RQ4. To what extent AAS publications are correlated time-cited?

RQ5.Which are the most highly-rated AAS Coronavirus publications?

\section{Method:}

Dimensions is a scholarly database, which included 110 million items as of 04-10-2020, each with an Altmetrics score (Dimensions, 2020). Papers with high Altmetrics Attention Scores (AAS)generally receive most attention from researchers, except in countries like China where many social media platforms are unavailable(Wang et al., 2016). In this study, we searched for high AAS papers on Covid-19 or Coronavirus indexed in the Dimensions database, using the key 
terms "Covid-19 or Coronavirus" and exported 100 papers with the highest AAS on 07-05-2020. These high AAS papers were published in 34 different leading journals or preprint repositories. Further, data was analyzed and calculated based on the objectives.

\section{Data analysis}

\section{The overall amount of posts for all Altmetric data resources:}

Generally, Facebooks and Twitter are the prominent social networking sites used by millions of people and share information worldwide. It is clearly shows from the (Fig.1) that, more than onethird of the total of 657350 posts was on the Twitter platform while the second highest number was 14318 in news, followed by Mendeley with 7310. At the other end of the scale books reviews and patents resulted in only one mention each, while QnA had five posts. Other social media attention ranged from 1567 in blogs to 13 in Google+ (Fig, 1).

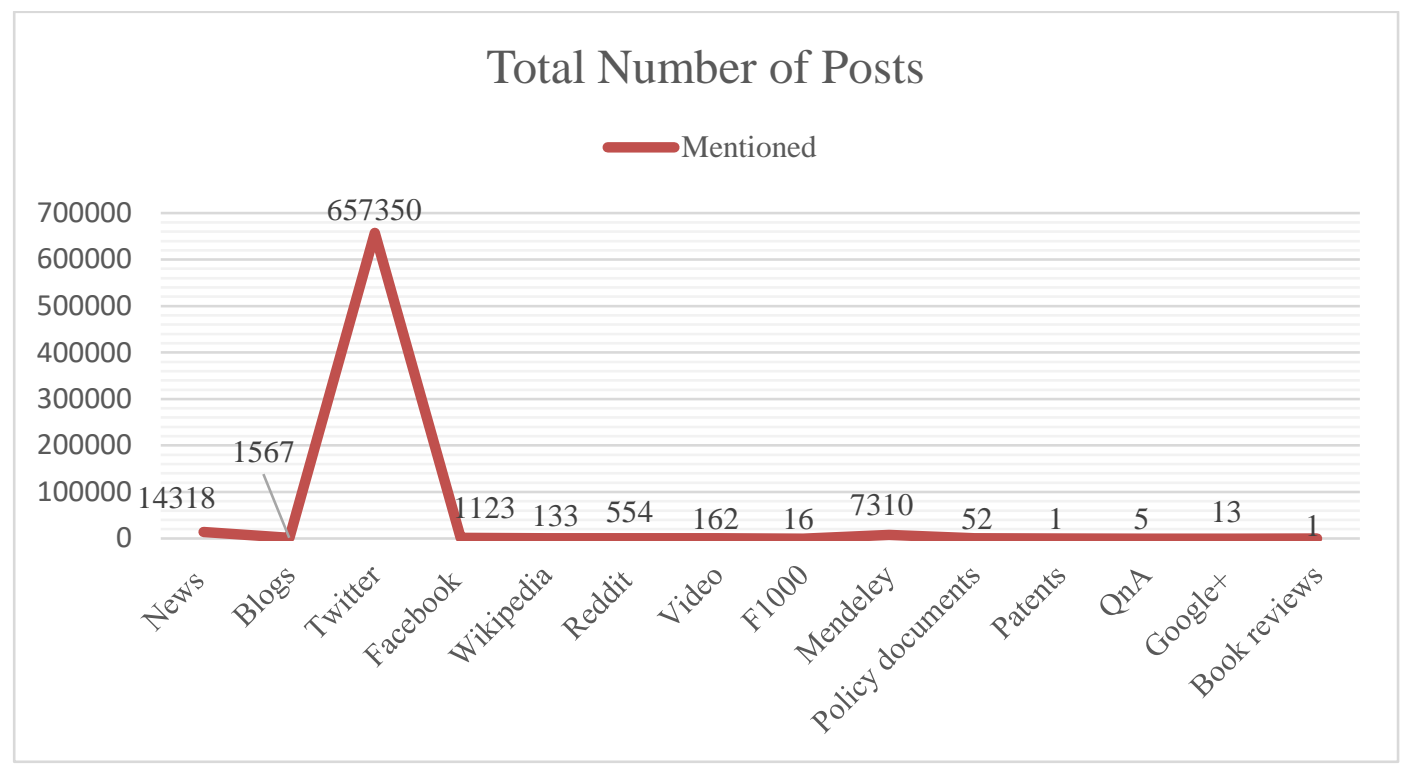

Figure 1. The number of posts for the top 100 AAS papers concerning "Coronavirus" in different data resources.

\section{Journals publishing the top 100 highly Altmetrics Attention Scores}

The vast majority of papers appeared in journals, such as New England Journal of Medicine, The Lancet, JAMA and Nature, that are ranked in the top 100 based on Google Scholar Metrics. The highest proportion (18\%) of Coronavirus papers appeared in the New England Journal of Medicine, followed by medRxiv, the preprint server for Health Sciences, with $12 \%$ (Table 1). Overall, slightly more than $50 \%$ of all publications were published in journals included in the top 100 publications. The Altmetrics score per paper (ASPP) was actually higher in lower-ranked (Google rank) journals such as Nature Medicine, Antiviral Research, Science, Journal of Hospital Infection and Virology Journal. Similar results were found in the case of the per-paper time cited score. The preprint server medRxiv had the lowest per-paper time cited score. 
Table.1. Source of publications with 100 high AAS papers. * mark represent that; the journals were not ranked google scholar in top 100 journals list.

\begin{tabular}{|c|c|c|c|c|c|c|c|c|}
\hline $\begin{array}{l}\text { Sl } \\
\text { No }\end{array}$ & $\begin{array}{l}\text { Publications } \\
\text { Source }\end{array}$ & $\begin{array}{l}\text { Percentage } \\
\text { s of Papers }\end{array}$ & $\begin{array}{l}\text { Googl } \\
\text { e } \\
\text { Schola } \\
\text { r } \\
\text { Metric } \\
\text { (h5- } \\
\text { index) }\end{array}$ & $\begin{array}{l}\text { Google } \\
\text { Scholar } \\
\text { Rank of } \\
\text { top } \\
\text { hundre } \\
\text { d } \\
\text { Journal } \\
\text { s }\end{array}$ & $\begin{array}{l}\text { Altmetric } \\
\text { s score }\end{array}$ & $\begin{array}{l}\text { Time } \\
\text { Cited }\end{array}$ & $\begin{array}{l}\text { Per-paper } \\
\text { Altmetric } \\
\text { s score }\end{array}$ & $\begin{array}{l}\text { Per- } \\
\text { paper } \\
\text { Time } \\
\text { Cited }\end{array}$ \\
\hline 1 & $\begin{array}{l}\text { New } \\
\text { England } \\
\text { Journal of } \\
\text { Medicine } \\
\end{array}$ & 18 & 352 & 2 & 160745 & 5828 & 8930 & 324 \\
\hline 2 & medRxiv & 12 & & & 89799 & 134 & 7483 & 11 \\
\hline 3 & The Lancet & 10 & 282 & 4 & 71074 & 5426 & 7107 & 543 \\
\hline 4 & JAMA & 8 & 211 & 15 & 62778 & 2422 & 7847 & 303 \\
\hline 5 & Nature & 6 & 368 & 1 & 37315 & 942 & 6219 & 157 \\
\hline 6 & Science & 5 & 338 & 3 & 58340 & 241 & 11668 & 48 \\
\hline 7 & $\begin{array}{l}\text { Emerging } \\
\text { Infectious } \\
\text { Diseases } \\
\end{array}$ & 4 & & & 31311 & 28 & 7828 & 7 \\
\hline 8 & $\begin{array}{l}\text { Nature } \\
\text { Medicine }\end{array}$ & 4 & 170 & 26 & 72147 & 317 & 18037 & 79 \\
\hline 9 & bioRxiv & 3 & $*$ & $*$ & 27776 & 48 & 9259 & 16 \\
\hline 10 & $\begin{array}{l}\text { MMWR } \\
\text { Morbidity } \\
\text { and } \\
\text { Mortality } \\
\text { Weekly } \\
\text { Report }\end{array}$ & 3 & * & $*$ & 22099 & 112 & 7366 & 37 \\
\hline 11 & $\begin{array}{l}\text { Proceedings } \\
\text { of the } \\
\text { National } \\
\text { Academy of } \\
\text { Sciences of } \\
\text { the United } \\
\text { States of } \\
\text { America }\end{array}$ & 2 & $*$ & $*$ & 11487 & 33 & 5744 & 17 \\
\hline 12 & $\begin{array}{l}\text { SSRN } \\
\text { Electronic } \\
\text { Journal } \\
\end{array}$ & 2 & $*$ & $*$ & 18866 & 34 & 9433 & 17 \\
\hline 13 & $\begin{array}{l}\text { The Lancet } \\
\text { Infectious } \\
\text { Diseases }\end{array}$ & 2 & 183 & 86 & 9520 & 115 & 4760 & 58 \\
\hline 14 & $\begin{array}{l}\text { Annals of } \\
\text { Internal } \\
\text { Medicine }\end{array}$ & 1 & $*$ & $*$ & 8419 & 183 & 8419 & 183 \\
\hline 15 & $\begin{array}{l}\text { Antiviral } \\
\text { Research }\end{array}$ & 1 & $*$ & $*$ & 12204 & 21 & 12204 & 21 \\
\hline 16 & $\begin{array}{l}\text { BioScience } \\
\text { Trends }\end{array}$ & 1 & $*$ & $*$ & 4342 & 205 & 4342 & 205 \\
\hline 17 & BMJ Open & 1 & $*$ & $*$ & 10750 & 36 & 10750 & 36 \\
\hline 18 & $\begin{array}{l}\text { Cell } \\
\text { Discovery }\end{array}$ & 1 & $*$ & $*$ & 4663 & 75 & 4663 & 75 \\
\hline 19 & $\begin{array}{l}\text { Cell } \\
\text { Research } \\
\end{array}$ & 1 & $*$ & $*$ & 6866 & 413 & 6866 & 413 \\
\hline 20 & ChemRxiv & 1 & $*$ & $*$ & 7992 & 0 & 7992 & 0 \\
\hline
\end{tabular}




\begin{tabular}{|c|c|c|c|c|c|c|c|c|}
\hline 21 & $\begin{array}{l}\text { Clinical } \\
\text { Infectious } \\
\text { Diseases }\end{array}$ & 1 & $*$ & $*$ & 4725 & 70 & 4725 & 70 \\
\hline 22 & $\begin{array}{l}\text { Clinical } \\
\text { Microbiolog } \\
\text { y Reviews }\end{array}$ & 1 & $*$ & $*$ & 9098 & 178 & 9098 & 178 \\
\hline 23 & $\begin{array}{l}\text { International } \\
\text { Journal of } \\
\text { Antimicrobia } \\
\text { l Agents }\end{array}$ & 1 & $*$ & $*$ & 7817 & 238 & 7817 & 238 \\
\hline 24 & $\begin{array}{l}\text { Journal of } \\
\text { Hospital } \\
\text { Infection }\end{array}$ & 1 & $*$ & $*$ & 12526 & 136 & 12526 & 136 \\
\hline 25 & $\begin{array}{l}\text { Journal of } \\
\text { Medical } \\
\text { Virology }\end{array}$ & 1 & $*$ & $*$ & 5576 & 120 & 5576 & 120 \\
\hline 26 & $\begin{array}{l}\text { Journal of } \\
\text { Travel } \\
\text { Medicine }\end{array}$ & 1 & $*$ & $*$ & 5667 & 27 & 5667 & 27 \\
\hline 27 & $\begin{array}{l}\text { MÃ@decine } \\
\text { et Maladies } \\
\text { Infectieuses }\end{array}$ & 1 & $*$ & $*$ & 5553 & 28 & 5553 & 28 \\
\hline 28 & $\begin{array}{l}\text { National } \\
\text { Science } \\
\text { Review }\end{array}$ & 1 & $*$ & $*$ & 7040 & 82 & 7040 & 82 \\
\hline 29 & Pediatrics & 1 & $*$ & $*$ & 6645 & 109 & 6645 & 109 \\
\hline 30 & The BMJ & 1 & $*$ & $*$ & 5580 & 7 & 5580 & 7 \\
\hline 31 & $\begin{array}{l}\text { The Lancet } \\
\text { Child \& } \\
\text { Adolescent } \\
\text { Health }\end{array}$ & 1 & $*$ & $*$ & 4397 & 3 & 4397 & 3 \\
\hline 32 & $\begin{array}{l}\text { The Lancet } \\
\text { Respiratory } \\
\text { Medicine }\end{array}$ & 1 & $*$ & $*$ & 6959 & 145 & 6959 & 145 \\
\hline 33 & Vaccine & 1 & $*$ & $*$ & 6903 & 0 & 6903 & 0 \\
\hline 34 & $\begin{array}{l}\text { Virology } \\
\text { Journal }\end{array}$ & 1 & $*$ & $*$ & 16111 & 182 & 16111 & 182 \\
\hline
\end{tabular}

\section{Geographic distribution of literature}

The highest proportion (29\%) of publications has been contributed by China, followed by the United States (26\%) and the United Kingdom (11\%). However, countries like Germany (6\%), Australia (5\%) and Italy (4\%) to the top 100 AAS papers related to Coronavirus (Fig. 2). While other countries (19\%) contributed 19\% literature related to the top 100 AAS papers related to Coronavirus. 


\section{Contribution of Publications by Country}

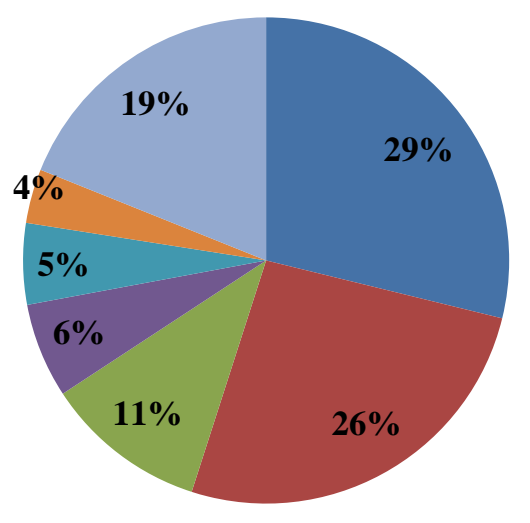

- China

- United States

- United Kingdom

Germany

Australia

Italy

Other Countries

Figure .2. Percentage contribution by country to the top 100 AAS Coronavirus publications.

\section{Distribution of publications by Institutes}

Of the 19 institutions that scored most highly in terms of publications on Covid-19 and coronavirus, the University of Hong Kong produced the most (12), followed by Wuhan Institute of Virology with seven. The remaining institutions produced here or four each (Table 2).

Table.2. Highest number of papers contributed by individual institutions to the top 100 ASS literature on Coronavirus.

\begin{tabular}{|r|l|r|}
\hline Rank & Organization & $\begin{array}{l}\text { No } \\
\text { Documents }\end{array}$ \\
\hline 1 & University of Hong Kong & 72 \\
\hline 2 & Wuhan Institute of Virology & 4 \\
\hline 3 & Chinese Academy of Medical Sciences \& Peking Union \\
\hline 3 & Chinese Center For Disease Control and Prevention & 4 \\
\hline 3 & Imperial College London & 4 \\
\hline 3 & Shanghai Jiao Tong University & 4 \\
\hline 3 & Tsinghua University & 4 \\
\hline 4 & Capital Medical University & 3 \\
\hline 4 & Centers For Disease Control And Prevention & 3 \\
\hline 4 & Charité - University Medicine Berlin & 3 \\
\hline 4 & Columbia University & 3 \\
\hline 4 & Harvard University & 3 \\
\hline 4 & University of California, Davis & 3 \\
\hline 4 & University of California, Los Angeles & 3 \\
\hline 4 & University of Cambridge & 3 \\
\hline 4 & University of Chinese Academy of Sciences & 3 \\
\hline 4 & University of Oxford & 3 \\
\hline 4 & University of Sydney & 3 \\
\hline 4 & Zhongnan Hospital of Wuhan University & 3 \\
\hline
\end{tabular}

\section{Comparison between Time-cited and AAS}

Among the top 100 AAS papers published in 2005, 2007, 2015 and 2020. It is clearly shown that the documents published in the year 2020 were high AAS followed by published papers in 2005 whereas paper published in 2007 and 2012 has low AAS. Similarly, the paper published in 2015 found high time cited while less time cited found in 2012. 


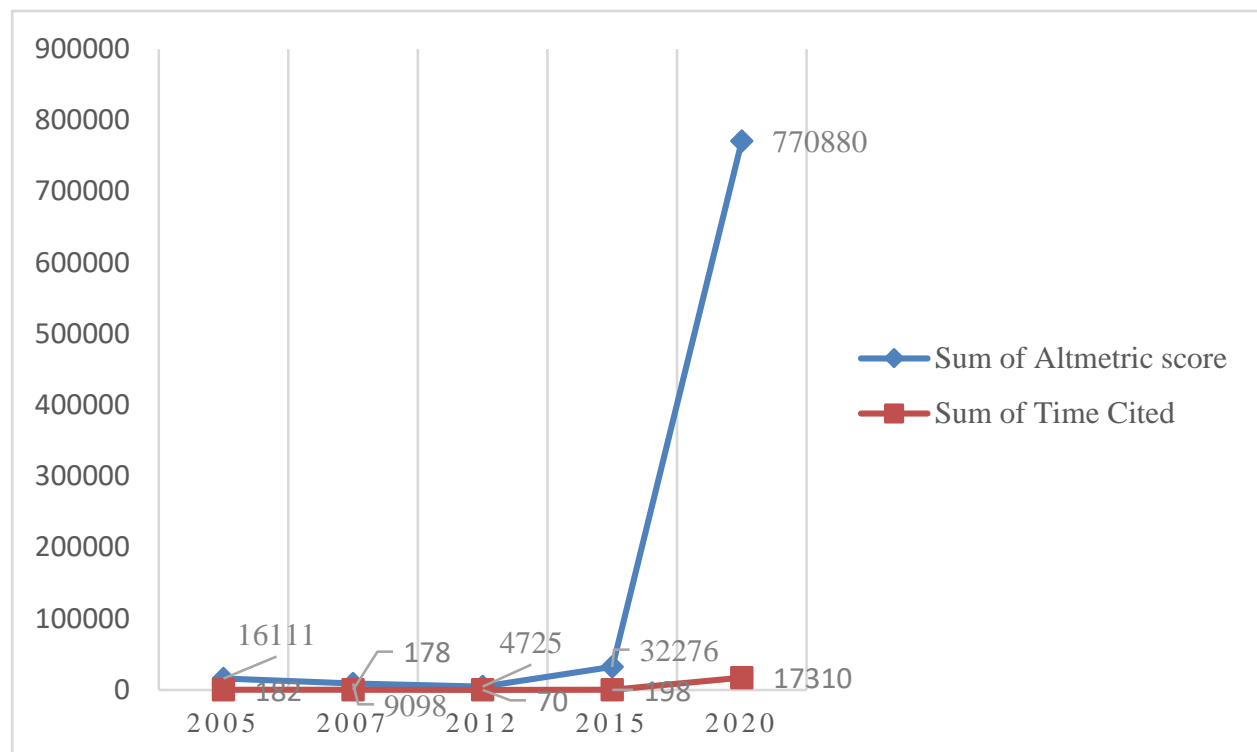

Figure.3. AAS compared with time-cited data collected from Dimensions database.

\section{Top Ten AAS Coronavirus publications}

The top 10 AAS range from 14987 to 33514. Apart from two papers published in preprint repositories (medRxiv and bioRxiv), all were published in high AAS journals. All but one of the papers was published in 2020. The exception was published in 2005. The paper published in the New England Journal of Medicine had the highest number of citations (281) although the journal is the second-ranked on AAS. One publication has yet to be cited at all.

Table 3.The top ten AAS publications with time cited and recent citations.

\begin{tabular}{|c|c|c|c|c|c|c|c|}
\hline $\begin{array}{l}\text { Sl } \\
\text { No }\end{array}$ & Title & Source & Authors & Year & $\begin{array}{l}\text { Altmetrics } \\
\text { Attention } \\
\text { score }\end{array}$ & $\begin{array}{l}\text { Times } \\
\text { cited }\end{array}$ & $\begin{array}{l}\text { Recent } \\
\text { citations }\end{array}$ \\
\hline 1 & $\begin{array}{l}\text { The proximal } \\
\text { origin of } \\
\text { SARS-CoV-2 }\end{array}$ & $\begin{array}{l}\text { Nature } \\
\text { Medicine }\end{array}$ & $\begin{array}{l}\text { Andersen, } \\
\text { Kristian G., } \\
\text { etal. }\end{array}$ & 2020 & 33514 & 104 & 104 \\
\hline 2 & $\begin{array}{l}\text { Aerosol and } \\
\text { Surface } \\
\text { Stability of } \\
\text { SARS-CoV-2 } \\
\text { as Compared } \\
\text { with SARS- } \\
\text { CoV-1 }\end{array}$ & $\begin{array}{l}\text { New } \\
\text { England } \\
\text { Journal } \\
\text { of } \\
\text { Medicine }\end{array}$ & $\begin{array}{l}\text { van } \\
\text { Doremalen, } \\
\text { Neeltje, et } \\
\text { al. }\end{array}$ & 2020 & 23649 & 281 & 281 \\
\hline 3 & $\begin{array}{l}\text { COVID-19 } \\
\text { Antibody } \\
\text { Seroprevalence } \\
\text { in Santa Clara } \\
\text { County, } \\
\text { California }\end{array}$ & medRxiv & $\begin{array}{l}\text { Bendavid, } \\
\text { Eran, et al. }\end{array}$ & 2020 & 21006 & 7 & 7 \\
\hline 4 & $\begin{array}{l}\text { Projecting the } \\
\text { transmission } \\
\text { dynamics of } \\
\text { SARS-CoV-2 } \\
\text { through the } \\
\text { post pandemic } \\
\text { period }\end{array}$ & Science & $\begin{array}{l}\text { Kissler, } \\
\text { Stephen } \\
\text { M., et al. }\end{array}$ & 2020 & 19545 & 21 & 21 \\
\hline 5 & $\begin{array}{l}\text { Substantial } \\
\text { undocumented } \\
\text { infection } \\
\text { facilitates the } \\
\text { rapid } \\
\text { dissemination }\end{array}$ & Science & $\begin{array}{l}\mathrm{Li} \text {, Ruiyun; } \\
\text { Pei, Sen, et } \\
\text { al. }\end{array}$ & 2020 & 17108 & 170 & 170 \\
\hline
\end{tabular}




\begin{tabular}{|c|c|c|c|c|c|c|c|}
\hline & $\begin{array}{l}\text { of novel } \\
\text { coronavirus } \\
\text { (SARS-CoV- } \\
\text { 2) }\end{array}$ & & & & & & \\
\hline 6 & $\begin{array}{l}\text { In Pursuit of } \\
\text { PPE }\end{array}$ & $\begin{array}{l}\text { New } \\
\text { England } \\
\text { Journal } \\
\text { of } \\
\text { Medicine }\end{array}$ & $\begin{array}{l}\text { Artenstein, } \\
\text { Andrew W }\end{array}$ & 2020 & 16756 & 0 & 0 \\
\hline 7 & $\begin{array}{l}\text { Respiratory } \\
\text { virus shedding } \\
\text { in exhaled } \\
\text { breath and } \\
\text { efficacy of } \\
\text { face masks }\end{array}$ & $\begin{array}{l}\text { Nature } \\
\text { Medicine }\end{array}$ & $\begin{array}{l}\text { Leung, } \\
\text { Nancy H. } \\
\text { L., et al. }\end{array}$ & 2020 & 16296 & 28 & 28 \\
\hline 8 & $\begin{array}{l}\text { Chloroquine is } \\
\text { a potent } \\
\text { inhibitor of } \\
\text { SARS } \\
\text { coronavirus } \\
\text { infection and } \\
\text { spread }\end{array}$ & $\begin{array}{l}\text { Virology } \\
\text { Journal }\end{array}$ & $\begin{array}{l}\text { Vincent, } \\
\text { Martin J, et } \\
\text { al. }\end{array}$ & 2005 & 16111 & 182 & 112 \\
\hline 9 & $\begin{array}{l}\text { Covid-19- } \\
\text { Navigating the } \\
\text { Uncharted }\end{array}$ & $\begin{array}{l}\text { New } \\
\text { England } \\
\text { Journal } \\
\text { of } \\
\text { Medicine }\end{array}$ & $\begin{array}{l}\text { Fauci, } \\
\text { Anthony S, } \\
\text { et al. }\end{array}$ & 2020 & 15920 & 81 & 81 \\
\hline 10 & $\begin{array}{l}\text { Uncanny } \\
\text { similarity of } \\
\text { unique inserts } \\
\text { in the 2019- } \\
\text { nCoV spike } \\
\text { protein to } \\
\text { HIV-1 gp120 } \\
\text { and Gag }\end{array}$ & bioRxiv & $\begin{array}{l}\text { Pradhan, } \\
\text { Prashant, et } \\
\text { al. }\end{array}$ & 2020 & 14987 & 13 & 13 \\
\hline
\end{tabular}

\section{Conclusion and Discussion:}

The present study was designed to determine the effect of high Altmetrics Attention Scores (AAS) papers relating to Coronavirus. Concerning the first research question, it was found more AAS collected from Twitter than other sources such as Blogs, Facebook, Wikipedia, Reddit, videos, F1000, Google+, QnA, and book reviews. Facebook has a greater membership but Twitter is clearly used much more by academics. Perhaps the most significant finding is that the top 100 AAS papers were published in 32 different sources, the majority published in New England Journal of Medicine and two preprint archives (medRxiv and bioRxiv). The possible explanation is that peer reviews journals articles go through the extensive peer review process, editing, copy editing etc. and it takes too much time so that, academic prefer to upload preprint papers in Preprint severs . It is clear that academic output has closely tracked the progress of Covid-19 around the world, with more papers from more institutions in China than anywhere else. The second highest research output comes from the USA, followed by the UK. Although the former was not the second country to be hit, it has a very high academic population. It is also clear that there has been an exponential increase in research published on Covid-19 and the coronavirus since the onset of the pandemic, with nine out of 10 of the most cited papers being published this year. What has emerged is the significant part played by the social media, especially Twitter, in broadcasting the results of this research. This is particularly important in view of the need for co-operation across the world to find an antidote for the disease. While the present study is restricted in its scope, it clearly shows the value of considering AAS in designing research projects where time is of the essence in disseminating results. 


\section{Acknowledgement:}

I would like to thanks to Dr D Margaret Avery FRSSAf, Emeritus Associate, Cenozoic Studies, Iziko Museums of South Africa, Honorary Research Associate, Evolutionary Studies Institute, University of the Witwatersrand, for her willingness to help and provide constant guidance, supervision.

\section{References:}

1. Araújo, R., Sorensen, A. A., Konkiel, S., \& Bloem, B. R. (2017). Top Altmetric Scores in the Parkinson's Disease Literature. Journal of Parkinson's Disease, 7(1), 81-87. https://doi.org/10.3233/JPD-179000

2. Babu, H. R., \& Vysakh, C. (2019). Citations v/s altmetric attention score: A comparison of top 10 highly cited papers in nature. Library Philosophy and Practice, 2019.

3. Banshal, S. K., Singh, V. K., Muhuri, P. K., \& Mayr, P. (2019). Disciplinary variations in altmetric coverage of scholarly articles. 17th International Conference on Scientometrics and Informetrics, ISSI 2019 - Proceedings, 2(October), 1870-1881.

4. Digital Science. (2018) Dimensions [Software] available from https://app.dimensions.ai. Accessed on (DATE), under licence agreement.

5. Dimensions. (2020). Dimensions.ai. https://www.dimensions.ai/

6. Dinsmore, A., Allen, L., \& Dolby, K. (2014). Alternative Perspectives on Impact: The Potential of ALMs and Altmetrics to Inform Funders about Research Impact. PLoS Biology, 12(11), 12-15. https://doi.org/10.1371/journal.pbio.1002003

7. Kim, J. E., Kim, Y., Park, K. M., Yoon, D. Y., \& Bae, J. S. (2019). Top 100 Publications as Measured by Altmetrics in the Field of Central Nervous System Inflammatory Demyelinating Disease. BioMed Research International, 2019. https://doi.org/10.1155/2019/3748091

8. Kolahi, J., Khazaei, S., Bidram, E., \& Kelishadi, R. (2019). Altmetric analysis of contemporary Iranian Medical Journals. International Journal of Preventive Medicine. https://doi.org/10.4103/ijpvm.ijpvm_134_19

9. Kousha, K., Street, W., Thelwall, M., \& Street, W. (2020). COVID-19 publications : Database coverage , citations , readers , tweets , news , Facebook walls , Reddit posts, 124.

10. Li, H. (2020). Coronavirus disease 2019 (COVID-19): current status and future perspectives. International Journal of Antimicrobial Agents, (January).

11. Moon, J. Y., Yun, E. J., Yoon, D. Y., Seo, Y. L., Cho, Y. K., Lim, K. J., \& Hong, J. H. (2020). Analysis of the altmetric top 100 articles with the highest altmetric attention scores in medical imaging journals. Japanese Journal of Radiology, (0123456789), 1-6. https://doi.org/10.1007/s11604-020-00946-0

12. Ram, S. (2020). Coronavirus Research Trends: A 50-Year Bibliometric Assessment. Science and Technology Libraries, 00(00), 1-17. https://doi.org/10.1080/0194262X.2020.1742270

13. Rangaswamy, \& H, R. B. (2019). An Altmetric Analysis of Top Journals in Library and Information Science. In Digital technologies and Transformation in Academic Libraries (Vol. 2, pp. 352-357). https://doi.org/10.6084/m9.figshare.11567901

14. Scotti, V., De Silvestri, A., Scudeller, L., Rebuffi, C., Topuz, F., \& Curti, M. (2020). Measure of Scientific Impact: How Altmetrics Can Innovate the Approach in a Multidimensional Model. Journal of Altmetrics, 3(1). https://doi.org/10.29024/joa.23

15. Thelwall, M., \& Levitt, J. M. (2020). Retweeting Covid-19 disability issues: Risks, support and outrage. El Profesional de La Información, 29(2), 1-6. https://doi.org/10.3145/epi.2020.mar.16 
16. Thelwall, M., \& Nevill, T. (2018). Could scientists use Altmetric.com scores to predict longer term citation counts? Journal of Informetrics, 12(1), 237-248. Retrieved from http://10.0.3.248/j.joi.2018.01.008\%0Ahttp://search.ebscohost.com/login.aspx?direct=tru $\mathrm{e} \& \mathrm{db}=1 \mathrm{lf} \& \mathrm{AN}=128275248 \&$ site $=$ ehost-live

17. Thelwall, M., Haustein, S., Larivière, V., \& Sugimoto, C. R. (2013). Do Altmetrics Work? Twitter and Ten Other Social Web Services. PLoS ONE, 8(5), e64841. https://doi.org/10.1371/journal.pone.0064841

18. Verma, S., \& Madhusudhan, M. (2019). An altmetric comparison of highly cited digital library publications of India and China. Annals of Library and Information Studies, 66(2), $71-75$.

19. Wang, X., Fang, Z., Li, Q., \& Guo, X. (2016). The Poor Altmetric Performance of Publications Authored by Researchers in Mainland China. Frontiers in Research Metrics and Analytics, 1 . https://doi.org/https://arxiv.org/ftp/arxiv/papers/1610/1610.07424.pdf

20. Wordl Health Organization. (2020). Coronavirus disease (COVID-19) pandemic. https://www.who.int/emergencies/diseases/novel-coronavirus-2019

21. Zhang, X., Estoque, R. C., Xie, H., Murayama, Y., \& Ranagalage, M. (2019). Bibliometric analysis of highly cited articles on ecosystem services. PLoS ONE, 14(2), 116. https://doi.org/10.1371/journal.pone.0210707 